\title{
Life after the Pandemic
}

\author{
Authors: Monica Hickson \\ Submitted: $\quad$ 19. September 2021 \\ Published: $\quad 20$. September 2021 \\ Volume: 8 \\ Issue: $\quad 4$ \\ Affiliation: University of Michigan, Ann Arbor, Michigan, USA \\ Languages: English \\ Keywords: $\quad$ Covid 19, Pandemic, loss, grief \\ Categories: News and Views, Humanities, Social Sciences and Law \\ DOI: $\quad 10.17160 /$ josha.8.4.780
}

\section{Abstract:}

The most difficult thing about re-entering into the world is learning how to deal with the past and what was left behind. Some are rushing to get back to the old way of life while some of us are still struggling to make sense out of all the pain in the midst of it. Returning to the way things used to be will never happen for those who have lost family members - sometimes multiple - to a senseless virus that wreaked havoc on the way we see the world in this pandemic era. 


\section{Life after the Pandemic}

\section{Monica Hickson}

Monica Website www.monicahickson.com

\section{MWC Reentry}

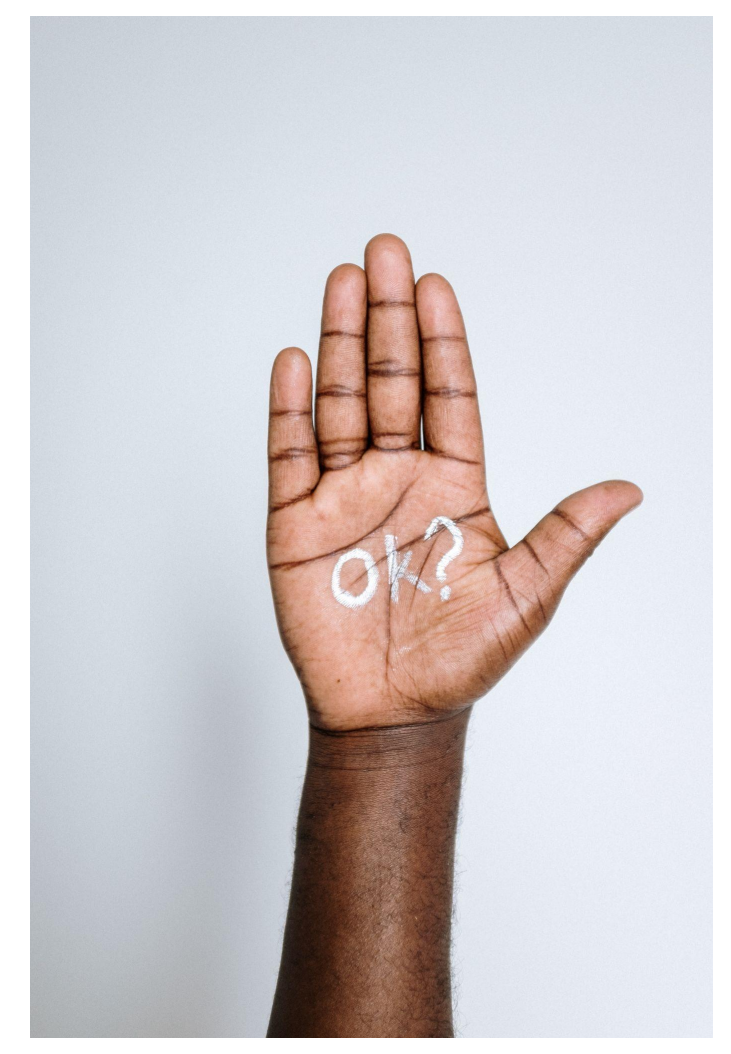

\section{Abstract}

The most difficult thing about re-entering into the world is learning how to deal with the past and what was left behind.

Some are rushing to get back to the old way of life while some of us are still struggling to make sense out of all the pain in the midst of it.

Returning to the way things used to be will never happen for those who have lost family members - sometimes multiple - to a senseless virus that wreaked havoc on the way we see the world in this pandemic era. 
'They' say the world would never be the same. Talks of a new normal loom. Many believe the pandemic is over but few really understand what that means to some of us. "We are heading back to the way things were," many argue. To me, there is no discussion. Reentry back into the communities, work, and world is like watching a child learning to walk. They cautiously stand and take that one small step before realizing they are losing their balance. I think of the lyrics of a popular song, "Put one foot in front of the other..." as I slowly open the door to a Post COVID World (PCW - a term I just coined).

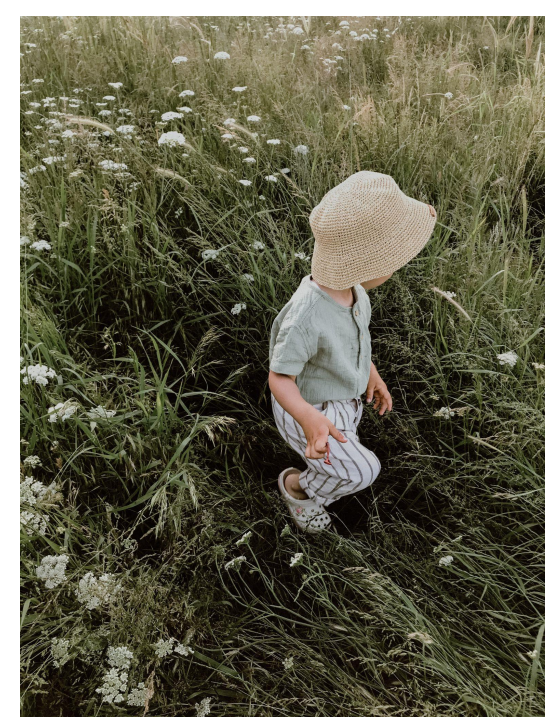

The most difficult thing about re-entering into the world is learning how to deal with the past and what was left behind. For me, it was my fiancé who died of COVID -19 in April 2020 during the pandemic. Hearing debates about what the new normal will look like is something that I can barely tolerate. In the PCW I left behind my friend, my warrior, my dance partner, and my sense of security. He was left on the other side of the door that I am trying to close but the winds of the Delta Variant keep the door open. As I awake every morning, I wonder how many more days we have to relive this nightmare. 
Returning to the way things used to be will never happen for those who have lost family members - sometimes multiple - to a senseless virus that wreaked havoc on the way we see the world in this pandemic era.

Some are rushing to get back to the old way of life while some of us are still struggling to make sense out of all the pain in the midst of it. Some are excited for new work from home schedules while others are forming new habits that were established during the pandemic. The grief that I personally experienced the last 15 months is unimaginable for most people to grasp. I had to say good-bye to my loved one on speaker phone because he had been on a ventilator for more than 21 days. I could not see him. I could not hold his hand as he left this world.

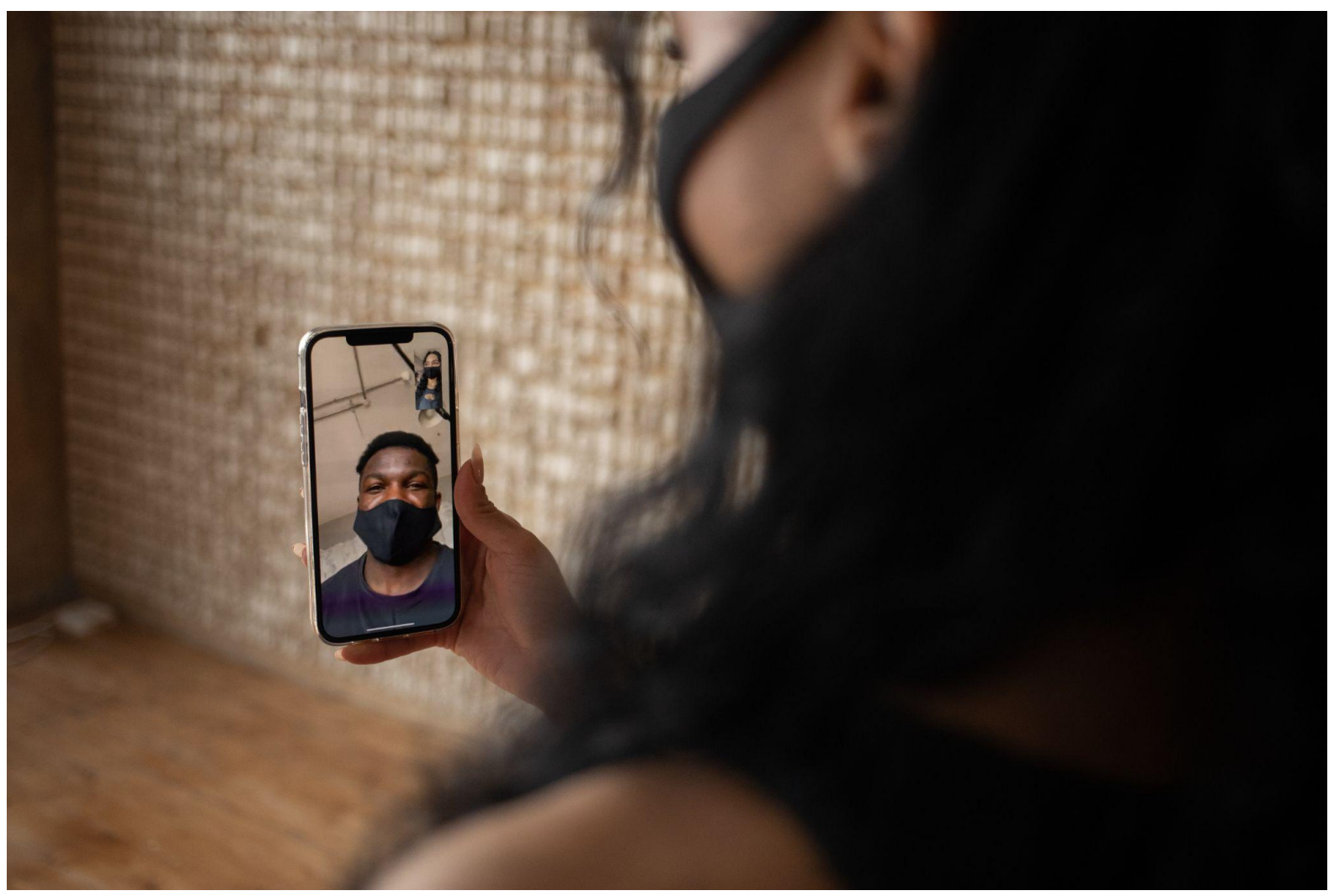

The mere idea of going back to normal makes me cringe because in the new world there are over 800,000 (and counting) people missing. There are parents without children, children without parents, grandchildren without grandparents and spouses or significant others without one another. These missing faces will never be reclaimed. Each holiday there will be empty seats at the dinner table. 
JOSHA

Journal of Science, Humanities and Arts

September 2021

Volume 8 , Issue 4

Many of us can't even think about a PCW but are longing to see our loved ones again in a parallel universe or in the afterlife one day. Never to return to the unreturnable era where people could walk freely without a decorative mask. A person could sneeze without causing a panic in aisle \#9 in the grocery store. A world where you could hug a mourning person after the death of their loved one. The new world. The one that is considered stable... until the next pandemic.

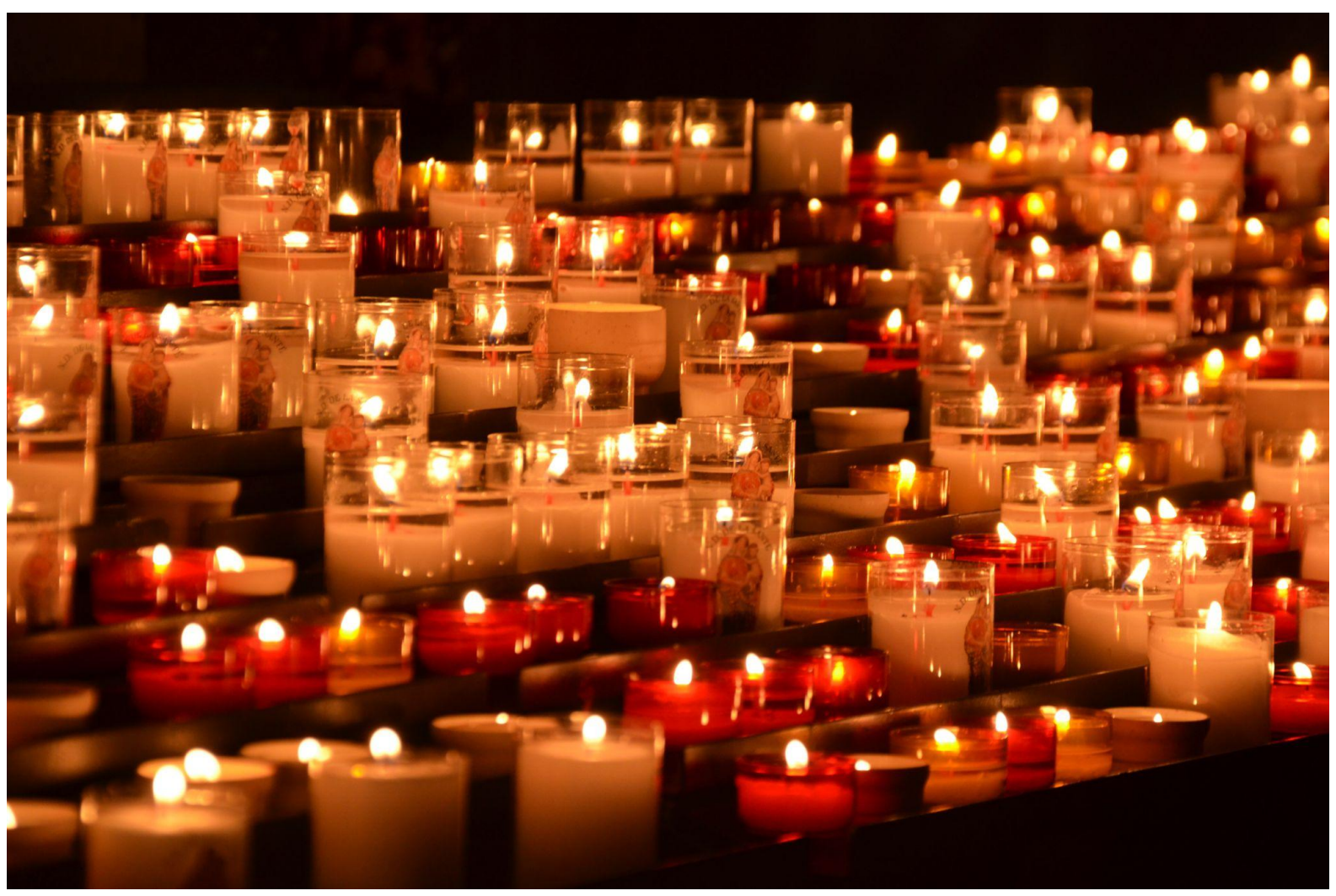




\section{About Monica}

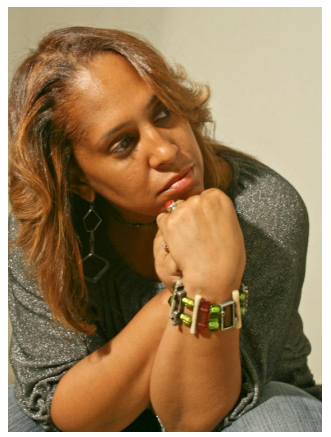

A true multitasker, Monica is a writer, instructional designer, diversity trainer \& facilitator, and educator who likes to stay abreast on a variety of topics. After losing her fiance to COVID-19 she has become an advocate for the people who have suffered during the pandemic and has written several articles and a book highlighting this turbulent time in our history.

You can find her original works and articles on Medium, Zora, The Shadow and several articles in Concentrate. Monica has been featured in several articles about the loss of her beloved David Reed due to

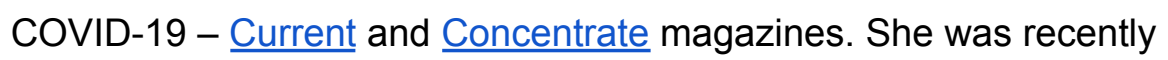
featured on a podcast in the Detroit Free Press, and will be appearing on another podcast in April 2021. Monica has appeared on Monica Morgan's radio show about Code Switching and Darwin Griffin television show both in February 2021.

Monica holds a Masters in Education from Central Michigan University. She prides herself on being a cool hip mom, cancer survivor, a divorce survivor, and a trusted advocate for those who need it. Monica's first book The COVID DIARIES hit Amazon February 2021.

Monica is passionate about voice over work and can be contacted through her website: www.monicahickson.com

\section{Favorites:}

Color: purple

Drink: chai tea

Love: family

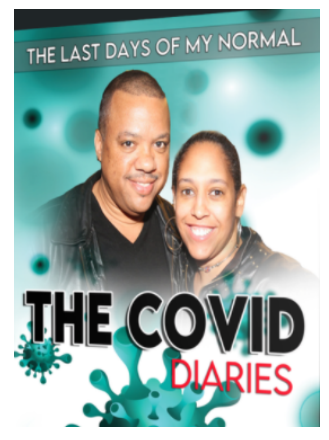

Author of The COVID Diaries, Freelance Writer, Instructional Designer and Life-long Learner and Educator 